\title{
Silver Recycling of Spent Photographic Fixer Solusion
}

\section{Jiro TANAKA}

\section{1.は じめに}

近年資源リサイクルが注目され，昨年 4 月には，“再 生資源利用促進法”いわゆるリサイクル法が，国会を通 過し，廃棄物の有効利用（資源化）を目的とした法律が, 制定された。廃棄物を原料として有効に利用することは 環境の保全にも寄与することとなり，また，鉱物や森林 などの資源の枯渴に対しても有効で，発生から回収，再 生利用までのしっかりとしたリサイクルシステムの確立 が早急に望まれる。

貴金属の要途は, 一般に装飾用としてのイメージが強 いが，近年工業面の利用も多くなり，スクラップの形状 も多様化しており個々の形状にあった回収技術，設備が 必要となる。

従ってスクラップの品位, 発生量が, リサイクル事業 のポイントとなる。

現在，金，銀，パラジウム，白金のリサイクル（再精 製）を事業としており，種々のスクラップを取り扱って いるが，今回使用量（発生量）の多い銀のリサイクルに ついて報告する。

\section{2. スクラップの発生}

銀の工業使用は，表 1 に示した様に，種々の業界で使 用されているが，写真感光剂用硝酸銀がもっとも多く，

需要の 50 ～55\%を占めている。

銀の使用形態は, $\mathrm{AgNO}_{3} \rightarrow \mathrm{AgBr}$ に加工され, ゼラチ ンでフィルムベースに塗布され, 製品として出荷される。 リサイクルの対象となるスクラップは, (1)定着廃液, (2)カラー漂白定着廃液, (3)使用済フィルム, (4)製品屑, (5)不良品, (6)Ag 含有污泥等で, 後者 3つ（4), (5), (6) はメーカーでの発生で, メーカー社内でのリサイクル,

* 平成 4 年 6 月 17 日本会第88回例会において発表

** (朝)日化学研究所

平成 4 年 4 月 16 日受理
衰 1 銀 日本の部門別需給 $(\mathrm{kg})$

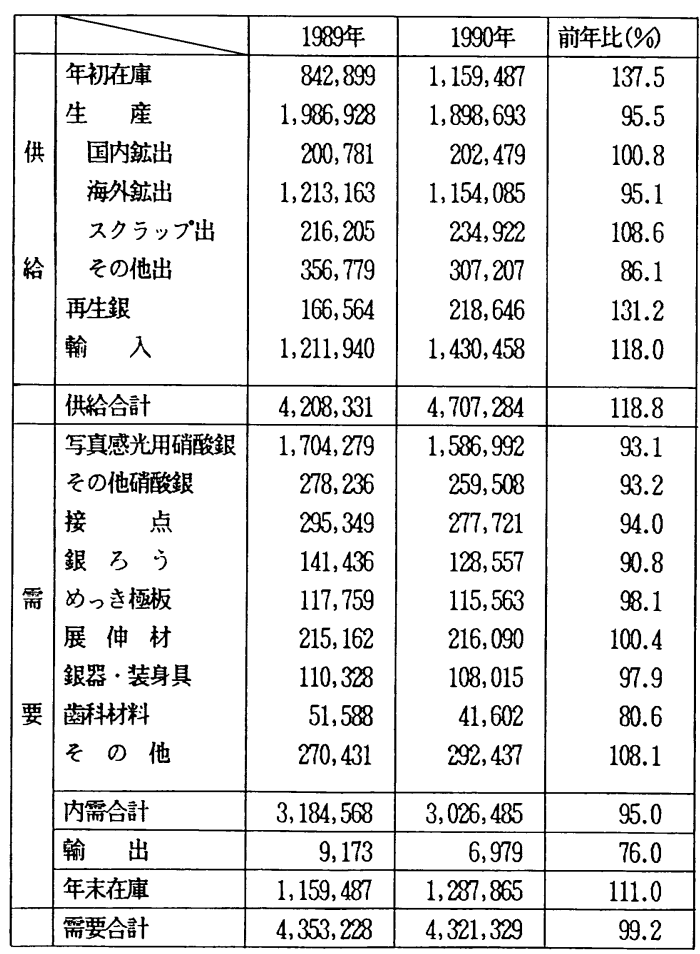

(エ業レアメタル103.ANUAL REVIEW'91)

もしくは山元還元が主となる。

リサイクル業務の対象となるのは，(1)〜3)の3つとな り, 病院, カラー現像所, カメラ店, 印刷所等から回収 する。

\section{3. 回収, 精 製}

因 2 に示した様に，フィルムは，まず焼却炬で焼却し たのち，この焼却灰から粗銀として回収する。（Ag 含有 率は，0.1\%〜 1\%から約 $50 \%$ となる) 


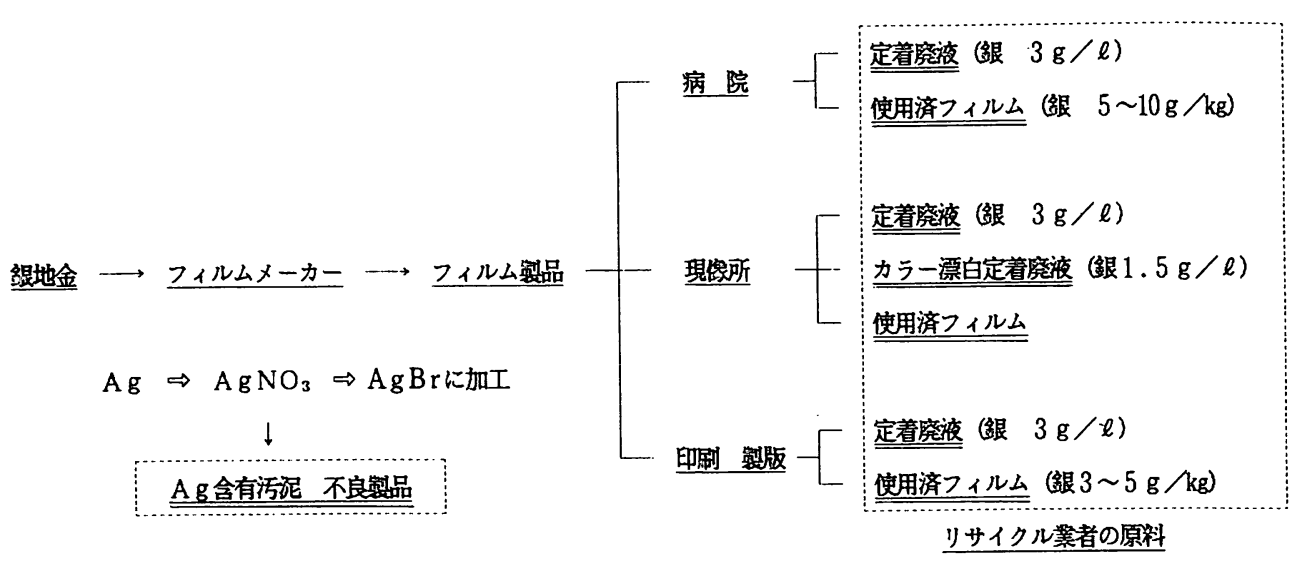

図 1 感材 銀スクラップの発生系統図

カラー漂白定着液は, 鉄ウールによる還元後, 熔融し て, 粗銀とする。定着液は, 円筒形回転陰極の電解機で 電析粗銀として回収する。

それぞれ回収された粗銀は, 熔錪してアノード銀とし， 精製電解をして, $99.99 \%$ 以上の電解銀となる。

\section{4. まと め}

最初に記述した様に，金，銀，バラジウム，白金のリ サイクル事業を行なっでり，効率的な回収技術の開発 や公害対策も大きな課題であるが，一方では，相場の動 向も大きく影響する。またりサイクル品の評価も低く， 行政的な面も含めて, 再資源システムの確立が必要であ る。

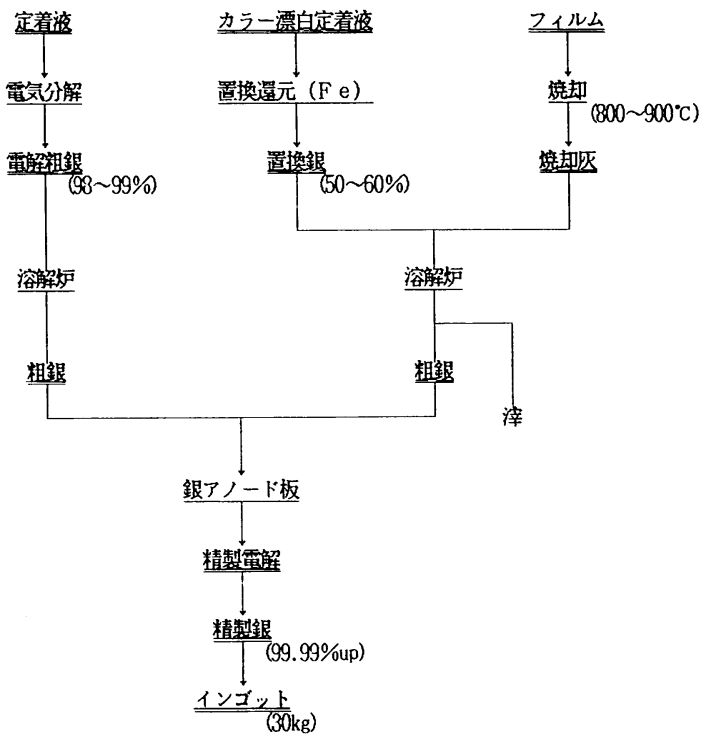

図 2 銀回収系統図 